\title{
Electron Microscopic Studies on the Ultrastructure of the Adrenal Cortex
}

\author{
Correlation of its Structure and Function
}

\section{Takeshi SATO}

The Ist Department of Internal Medicine, Niigata University School of Medicine

(Director : Dr. Mitsuo Nishikawa)

Electron microscopic studies were made on the morphological changes of mitochondria of the adrenal cortex of young and mature rats under various experimental conditions: administration of ACTH, DOGA, chorionic gonadotrophin and $\mathrm{KGl}$ with accompanying decrease in $\mathrm{Na} / \mathrm{K}$ ratio, removal of hypophysis, etc. Correlation between the ultrastructure of the adrenal cortex and its function was sought.

1) Mitochondria can be classified into two types according to the structure of the internal membrane : type I with the internal membrane possessing crista-like or filament-like structure and type II with the internal membrane of honeycomb-like structure. The former is mainly found in the zona glomerulosa and the latter in the zona fasciculata and reticularis. As the rat matures or as hyperfunction of the adrenal cortex develops, the type I mitochondria become more complex in structure with the protruding structure of the internal membrane forming a fine network. The type 1 mitochondria are transformed into type II. When hyperfunction of the adrenal cortex persists, the limiting membrane of mitochondria breaks and the internal structures of mitochondria come into contact with the endoplasmic reticulum surrounding the mitochondria.

2) The structure of mitochondria in the zona glomerulosa is altered when either the $\mathrm{Na} / \mathrm{K}$ ratio is lowered or DOGA is administered. A similar change can be observed with the adminisiration of ACTH or by hypophysectomy. The function of the zona glomerulosa, therefore, seems to be under the influence of the alteration of the $\mathrm{Na} / \mathrm{K}$ ratio as well as the function of the hypophysis, though to a lesser extent.

3) With the administration of chorionic gonadotrophin, a tubular structure appears in the type II mitochondria in the inner layer of the zona fasciculata and in the outer layer of the zona reticularis. This structure, after six weeks administration of chorionic gonadotrophin, changes into a vacuolar structure.

These changes in the mitochondria differ from those seen after the administration of AGTH, e.g., disappearance of the fine structure in the internal membrane of the type II mitochondria in the outer layer of the zona fasciculata and opening of the limiting membrane.

Vol. 38 No. 9 


\section{副腎皮質の電子顕微鏡学的研究}

——超微細構造と機能との関連について——

新潟大学医学部西川内科教室（主任 西川光夫教授）

佐藤猛

(昭和 37 年 5 月 25 日受付)

\section{1. 緒言}

従来, 副腎皮質の構造と機能との相関について，皮質細胞の層的配列という観点に立脚した機能的二元論 が提唱されてきた (Greep \& Deane $\left.{ }^{1)}\right)$. 即ち, 球状層は鉱質ホルモンを分泌し, 脳下垂体前葉の支配からは 独立する。一方，束状首及び網状層は ACTHにより支配され，糖質ホルモンを分泌するという考光である。 てれに加え, 性ホルモンも東状層内層或いは網状首から分泌されるのではないかという推測が BottellaLlusia ${ }^{2}$ 及び Jones ${ }^{3}$ )等によりなされている.

近年, 電子顕微鏡の発達に伴ない, 細胞内の超微細構造と機能の関連か脚光をあびてきた。即ち Braunsteiner $^{4)}$, Lever ${ }^{5 \sim 7}$ ), Belt ${ }^{8}$, De Robertis ${ }^{9}$, Ross ${ }^{10)}$, Geyer ${ }^{11)}$, Asworth ${ }^{12)}$, Zelander ${ }^{13)}$, 木陣 ${ }^{14)}$, 坂元 ${ }^{15)}$, 吉 村 ${ }^{16)}$ ，斎藤藏等は Mitochondria (以下 Mit. と略す)，小胞体等の各 organella が副婜皮質の機能に伴な つて変化するてとを電顕的に観察している。

生化学の領域から Steroid Hormone の生合成の際, 重要な役割をもつ醉素が Mit. 及び小胞体隹多く会 有されているてとが指摘されているてと ${ }^{18)}$ を考光合せる時，てれら organella の構造の変化を追求する意 義が大となつてくる.

西川, 室根及び著者 ${ }^{19}$ はラットに AGTH 投与, 脳下垂体摘出, Gonadotrophin 投与等の実験を行ない, 電䫓的観察から，副婜皮質細胞の organella の形態の変化と機能との関連を推論した。

その結果, 副腎皮質の Mit. は cristae 或いは filament 状の比較的簡単な内膜構造から, 複雑な蜂窩状 の内膜構造へと発達してゆくと推測した，この点について，幼若ラットの副掔皮質の超微細構造の検討によ つて更に確かめた。

次に ACTH で刺激すると束状㬝外層の Mit. が反応し， Chorionic Gonadotrophin で刺激すると束状

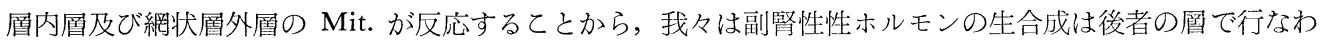
れるのであらうと考光た。乙れに電解質代謝の実験も加光て, 球状首細胞の微細構造の変化を観察し, Functional zonation の問題に检討を加光た.

\section{2. 実験材料及び方法}

Wistar 系雄性ラット (平均体重 $150 \mathrm{~g}$ ) を用い, 各群を 3 〜 5 匹とし, 下記の実験を行なつた.

第 1 群: 正常成熟ラット群.

第 2 群: 生後 5 日（体重8g）及び12日（体重 $18 \mathrm{~g}$ ) の未熟ラット群.

第 3 群 : ACTH-Z 投与群. ACTH-Z 3mg 一回筋注後12，24，36時間後屠殺，及び ACTH-Z 4mg/日 を $1,2,3$ 週間連続投与群.

第 4 群: 脳下垂体摘出後 $1,3,4,7,8$ 週間後に屠殺した群.

第 5 群 : KCl 投与群 : 脳下垂体摘出後 8 週間及び未摘出のラット群を用い, 一側副腎を $\mathrm{KCl}$ 投与前日 にあらかじめ摘出しておき，対照とした。体重 $100 \mathrm{~g}$ 当り KGl $15 \mathrm{mg}$ を $1 \%$ 水溶液として， 3 回に分け 6 時 間の間に腹腔内に注射, 初回注射より11及び24時間後に他側副腎を摘出検索した.

第 6 群 : DOCA 投与群 : 体重 $100 \mathrm{~g}$ 当り $0.025 \mathrm{mg}$ を 5 及び 8 週間連続筋注した. 
第 7 群 : Chorionic gonadotrophin 投与群 : 去勢及び未処置ラットに Primogonyl (Schering) 1 回50単 位を週 2 回， $2,3,4$ 及び 6 週間筋注.

以上の各群の動物は断頭曆殺後, 直ちに副腎を摘出, $\mathrm{pH} 7.4$ 燐酸緩衙 $1 \%$ Osmium 酸固定液中にて, 長 軸が必ず副腎の中心を通る幅及び厚さ $1 \mathrm{~mm} の$ 組織片に細分し，氷室中で 3 時間固定した．終了後水洗し， $70 \%$ か始まる Alcohol 系列にて脱水。包埋は n-Butylmethacrylate 8 と-Methylmethacrylate 2 の 制合にて混合した monomer を使用し，最初 $30^{\circ} \mathrm{C}$ の孵卵器巾で 3 洔閒，次いで $45^{\circ} \mathrm{C}$ 中に一昼夜入れて重合 した.

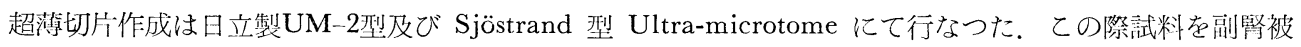
膜から髄質に向う軸に，切片の長軸が平行になるような短朋型に整形して，切片を作成した。 てれをスりッ ト・メッシュ及びシート・メッシュにのせて，電子顕微鏡にて観察の際，細胞の層的な仙置関係がはつきり 分るようにした(Fig.17参照).

電子顕微鏡は日本電子社製 JEM-5G及び明不製 TRS-50型を使用した。

なお他側副婜はH-E染色，Sudan Black 染色をほどしし参考に供した。

\section{3. 観 察 所 見}

\section{(1) 正常成熟ラット}

副骳皮質の Mit. はその内膜構造により，2型に大则され，乙れらは皮質の各貭における分布も異なつて いる.

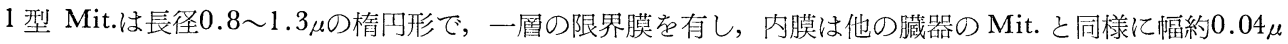
の cristae 或いは filament 状の構造を呈している. Mit.の matrix には微細顆粒も存在する。乙の型の Mit. は主に球状層の被膜隣接の細胞に多く分布する (Fig. 1)。球状萿の内尿になるに従つて，乙の filament 状の内膜突起は不規則に蛇行し，その断㑑は刚形或いは桿状を是し，構造が複雑になり次に述べるII 型 Mit. への移行型となる.

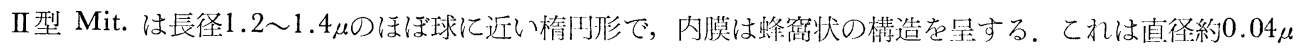
の小球状或いは短桿状の胞体が密に配列していると考えられる(Fig. 2)。乙のII型 Mit. は束状首及び網状 層に多く分布する．かかる構造の Mit. は副腎皮質の他には宰丸の間質細胞，卵雀の黄体細胞，バッタの監 蔵 $^{20)}$ 及び或る種の原虫類 ${ }^{21)}$ の Mit. にみられる。

束状層内層及び網状層になるとII 型 Mit. の内部構造の一部が棍棒状又は短管状になつており，matrixの 電子密度も高い. 便宜上, 前記 Mit. をII A型, かかる Mit. をII B 型とした (Fig. 3 及び Fig. A 参照)。

ラット副腎皮質で従来から闆題になつている移行風は，電顕でも観察され，扁平な暗細胞から成り，Mit. はII B 型を旺する.

小胞体は直径 $0.17 \sim 0.2 \mu$ 滑面小胞体で，乙れも皮質各層に打ける分布状態が異なつている．球状層では vesicular type のものが数多く存在するが，東状首，網状㐿では少ない，てれらの風は大部分喑細胞で構成 されているが，明細胞ではやはり vesicular type の小胞体が垫められる(Fig. 3 ).

脂質顆粒は一層の薄膜に包まれる。球状層では直径 $1 \mu$ 前後の大きさのほぼ一定した球形の顆粒が，しばし ば，集団をなしているが，束状層，網状風では直径 $2.7 \mu$ 前後の大きな球形のものが散在している。網状層の 髄質に近接した細胞には直径 $3 \mu$ 以上の更に大きな顆粒もある。

この脂質顆粒にはしばしば Mit. が密に接している像がみられる(Fig. 1，7)。この脂貿顆粒の形成につい ては次の項で述べる。

\section{（2）末熟ラット群}

生後 5 日及び12日目の未熟ラットに共通している特徵は，成熟ラットに比し，球状層及び束状睳の細胞内 に含まれる Mit. の密度が非常に少ないてとである。この傾向は 5 日目の方が著明である。換言すれば，成 熟度に比例して Mit. の数が増加する(Fig. 5，6，7，8)。したがつて細胞質は明調を景し，束状首内風にな 
つてはじめて暗細胞が観察される。

又，Mit. の構造は比較的冒純であり，I型 Mit. が束状層外周でも浔められる。成熟するに従つて内膜の 構造が複雑となつて， I型 Mit. へと進展するのではないかと推察される.

Mit. と同様, 小胞体並びに Golgi apparatus の発達も悪いが, Palade 顆粒は多数認められる. Rouiller \& Bernhard ${ }^{22}$ 及び Belt ${ }^{8}$ により Mit. の前駆体と考朰られた microbody は成熟ラットでは主に球状尿に散 胃されるに過ぎないが，未熟ラットに於ては球状層から束状層外層にまで比較的多数浔められる(Fig. 6, 8).

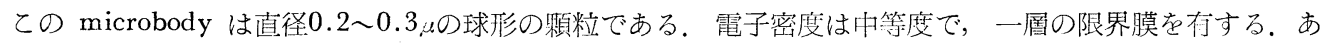
るものは cristae 様の内部構造を是し, Mit. への移行像と推察される.

脂質顆粒も未熟ラットの副筱では発達が悪い。乙の脂質顆粒の形成について Lever ${ }^{7} は$ Mit. の内部に電 子密度の高い物質が沈着して，乙の沈着が次第に増加して脂質顆粒が形成されるのではないかと示唆してい るが, degeneration の場合を除いて，Mit. 内に脂質顆粓の沈着が観察されることは極めて稀である。むし ろ小胞体の内部に電子密度の高い物質が沈着しているととが多い.この物質が集合し，融命して脂質顆粒が 形成されると想像される。

\section{(3) ACTH-Z 投与及び脳下垂体摘出の影響}

\section{a) ACTH-Z 投与の影響}

ACTH で刺激すると束状層外首に最も著明な变化が起る。II型 Mit. は膨大し，蜂䆚状の内膜の一部は 消失し，Mit.の matrix の電子密度は低下して明調を呈する。或る Mit. では，限界膜の一部か潤裂して， Mit. の内部と周辺の原形質や小胞体等と接触するようになる。ACTH の投与期間が長くなる程，かかる傾 向は著明になる(Fig.10)。かくの如き Mit. の形態の変化の過程をFig.Aの模式戍で示した.

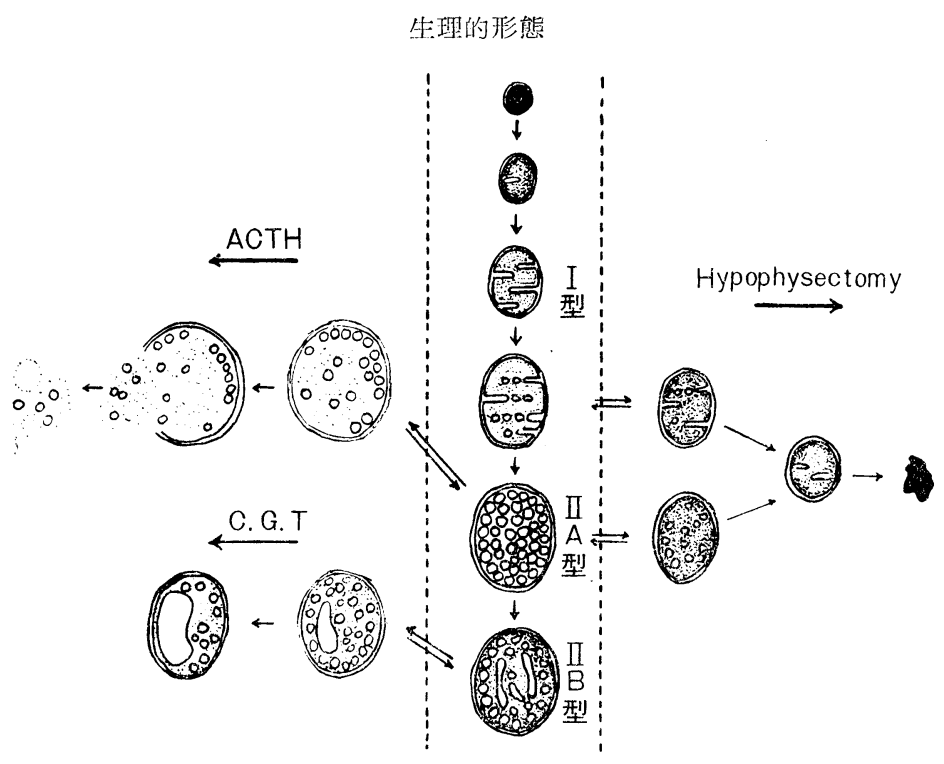

Fig. A 副檑皮買 Mitochondria 形態の変遷

小胞体も数，大きさ共に增加し，Golgi apparatus も発達する。乙れに加え細胞内に palade 顆粒及び直 径約 $0.04 \mu$ の特殊な小胞も増加する。乙の特殊な小胞と Mit. の内济とは構造が似ており, Mit. の限界膜の 開裂部を通じて両者が深い相互関係を有する.

脂質顆粒については ACTH の投与期間が長いほど減少が著明である．正常では球形のこの顆粒が種々の

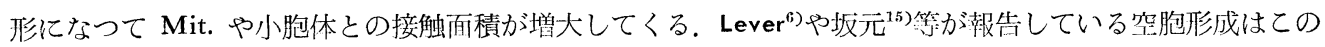


脂質顆粒内には認めなかつた。 又，脂質顆粒の血管腔内への直接の分泌像は認められなかつた。

次いで球状層に対する影響についての観察所見を述べることにする.

既に光顕像にて ACTH が球状筩にも刺激的に作用することが報告されており，電顕像でも Lever ${ }^{6)}$ が同 様の結果を報している。我々の所見でも ACTH 投与後 1 週間群で既に球状層の Mit. は束状首と同様に膨 大，或いは長さが狿長し棍棒状になる。，又，I 型 Mit.の filament 状内膜突起は数が増加し，蛇行して複 椎になり，移行型 Mit となる。更に刺激が続く場合は限界膜の開裂も起る(Fig. 9).

球状首の脂質顆粒は ACTH 投与 3 週間の群で若干減少するが，束状首ほど強い減少はない.しかし，

Fig. 9 の如く, 脂質顆粒の集団を桿状に長くなつた Mit. が取り国んでいる興味ある所見が観察された。

Microbody の增加も起り, 殊飞被膜隣接細胞でしの傾向が著しいように思われる.

\section{b) 脳下垂体摘出の影響}

束状層及び網状層では術後 1 週間群で既に機能低下像が認められる。Mit. は萎縮し，内部の電子密度が 高まり，構造は不明膫になつてくる(Fig. 12)。萎縮が高度になると Mit.の matrix の電子密度は更に高ま り，終には無構造の顆粒になる。網状層ではての顆粒がいくつか集合して大きな塊を形成しているものも認 められた(Fig.13).

小胞体，Golgi apparatus 及び palade 顆粒も減少する．脂質顆粒は粗大化する．原形質の電子密度が高 まつてくるため，細胞は暗調を帯びてくる.

球状層は脳下垂体摘出により幅が厚くなり，移行層の幅も厚くなるてとが既に報告されているが（Deane \& Greep 1946 $\left.6^{23}\right)$, 本実験でも術後 1 週間目から球状首の幅は厚くなり, 移行首の幅も拡大してくる. しか し，Mit. は 1 週間目ではむしろ内膜の構造が複雑化し，移行型 Mit. に近い像を呈していた，Lever ${ }^{6)}$ は術 後 9 週の群で Mit. の萎縮が起ると報じているが，本実験では術後 8 週で Mit. の内膜突起が減少し，その 突起の間にオスミウム好性物質が沈着し，構造が不明膫になつてくる。

小胞体, Golgi apparatus も同様に減少してくる.

\section{(3) $\mathrm{Na} / \mathrm{K}$ 比の低下及び DOCA 投与の影響}

\section{a) $\mathrm{KCl}$ 投与による $\mathrm{Na} / \mathrm{K}$ 比の低下}

$\mathrm{Na} / \mathrm{k}$ 比の低下が球状㐿より Aldosterone 分泌を促進させ，逆に $\mathrm{Na} / \mathrm{K}$ 比の上昇が分泌を抑制するてと が知られている ${ }^{24) 25)}$.

$\mathrm{KCl}$ 投与後11時間にて, 脳下垂体摘出及び非摘出ラット群共に球状層の organella の形態の変化が惹起 される。乙の変化は ACTH で刺激された場合と似ている。即ち Mit. は膨化し， I 型 Mit. の filament 状の内膜突起は数が增加すると同時に不規則に蛇行し，移行型 Mit. になる (Fig.15). Mit. の数も増加し， 中には限界膜の開裂しているものもある。乙の開裂部を通じて Mit. 内部と周辺の細胞質とが接触している。

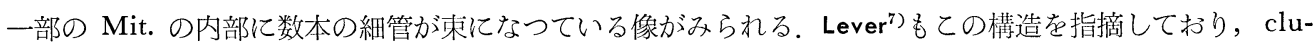
ster と称している. 彼はこの cluster とGolgi 膜と形熊が似ているととから Golgi apparatus から Mit. が形成されると仮定している。しかし，乙の cluster の断面をみると，Golgi 膜の断面像とは異なり，かな り多数の細管が束になつている(Fig.15). 又, 位置的にも Golgi apparatus とは異なり，核から遠く離れ た細胞膜に近い場所の Mit. にもこの cluster が認められる. 以上の事実から Lever の仮定は肯定し難い. vesicular type の小胞体及び Golgi apparatus も著明に発達する. 脂質顆粒は数, 大きさ共にあまり変 化しない.

$\mathrm{KCl}$ 投与後 24 時間の群では，11時間の群よりやや organella の変化が少なくなつている.

\section{b) DOCA 投与の影響}

投与開始後 5 週で，皮質全層に萎縮が起るが球状層の変化が最も著しい.

Mit. は菱縮し, 内膜の構造は単純になる. 即ち filament 状の内膜突起は短かく真直になり, 数も減少す る。そのため球状屏内首になつても Mit. はI 型を呈する. 減少した cristae の間に電子密度の高い物質が 沈着し, Mit. の構造は不明瞭になつてくる(Fig.16)。乙の Mit. の萎縮の状態は脳下垂体摘出時と同一であ 
る.

小胞体及び Golgi apparatus も減少し，細胞は暗調を呈する，かかる暗細胞の增加は DOCA 投与 5 週 間の群の方が 8 週間の群より著明である. Sarason ${ }^{26}$ 或いは Deane \& Greep ${ }^{24}$ は DOCA か 球状首の脂質顆 粒をを撰択的に減少させると報告しているが，Selye \& Stone ${ }^{27}$ ) は減少を認めていない，著者の実験では， Sudan B 染色で, 光顕的にも DOCA 5 週間投与群で軽度の減少, , 8 週間群で高度の減少を観察し，才ス ミウム固定による電顕的観察でも同様に脂質顆粒の高度の減少が認められる。

脳下垂体摘出の場合，球状層の脂質顆粒はほとんど变化しないか，むしろ粗大化する㖽向にあるが，乙れ と比較すると, DOCA 投与の場合減少が起るのは特異的な変化である.

\section{(4) Chorionic Gonadotrophin 投与の影響}

Chorionic Gonadotrophin (G.G.T.) を投与すると束状層内凰及び網状居外网の Mit. に特異的な変化が 进る。即ち C.G.T. 投与 3 週でこの首の Mit. の内部に管状構造が生じ，II B 型になる。 6 週月になるとて の管状構造が拡大し，内部に電子密度の低い物質を満たす空胞様の構造になる(Fig.14)。しかしながら，球 状凮及び束状首外風の Mit. は変化しない.

ACTH で刺激すると Mit. の限界膜は開裂するが， C.G.T. の場合かかる像は認め得なかつた，両者の Mit. の形態の変化の相違を模式的に Fig. Aにて示した.

Vesicular type の小胞体も束状風内層及び網状首外㬝では柽度の增加を示す．Golgi apparatus はほと んど不変である。

網状層の内居，即ち juxtamedullary layer は G.G.T.でもACTHでも刺激を受けない，ての首はもは や機能を有しない degeneration に陥つた細胞の首とみなされる。

\section{4. 考按及び総括}

副婜皮質の Mit. 小胞休等の各 organella は皮質の機能に応じて形態が变化するが，次の諸点を中心に考 察をすすぬて，Steroid Hormone の生合成におけるてれら organella の役割を明らかにしようと試みた。

即ち，(1) Mit. の新生と形態の変化 (2) 副腎皮質の機能と Mit. 及び小胞体の形態の変化との相互関係 (3) 副腎皮質の organella の微細構造に立脚した Functional zonation への批判である.

\section{(1) Mit. の新生と形態の変化}

\section{a) Mit. の新生}

Mit. の起源については未だ定説なく，従来の説には microbody より新生されるというもの (Rouiller \& Bernhard $^{22}$ 及び Belt $\left.{ }^{8}\right)$, Golgi apparatus から形成されるというもの (Lever $\left.{ }^{7}\right)$ がある. microbody から形

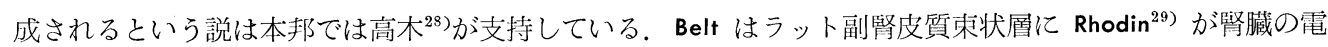
顕像で名付けた microbody と同一の構造の顆粒 $(0.2 \mu)$ を見出しており, Mit. と脂質顆粒の両方の前駆体 と考光た．乙の microbody を同定する場合，Mit. 或いは脂質顆粒が切線方向に接する面で薄切された㭙 の像との鑑別が問題となり，かなり困難である．著者は直径 $0.2 \sim 0.3 \mu$ の中等度の電子密度の顆粒で，一 層の限界膜を有するものを microbody とみなした。 この microbody は成熟ラット副腎では球状凮の被 膜隣接細胞に見られ，未熟ラットでは球状層内層，束状層外層に至るまで垫められる，又，ACTH で刺激 すると，Mit. が増加すると同時に microbody も増加する。乙のように Mit. の新生が促されるような㭙 microbody が增加するとと，比較的未熟な細胞に多いとと，かつ若干の microbody は不明膫ながら， cristae 様の内膜構造を有するととなどから, microbody が Mit. へと進展すると考学られる.

次に，Lever は Mit. の内膜と Golgi 膜とが似ていることから, Golgi 膜から Mit. 新生の可能性を推測 しているが，KCl 投与時副腎の項で述べた如く，両者の断面の構造が異なつている点，又，未熟ラットで は Glogi 膜に似た構造の Mit. が発見されなかつた点などから, Golgi 膜を Mit. の前駆体とは考光難い。

さて，乙の microbody の前駆体は如何なるものであろうか. Belt はこれについては記載していないが， 高木 ${ }^{29}$ は滑而小胞体内へ微紐頪粒状基質が蓄積して生ずるのではなかいと想像している，未熟ラットの球状 
首及び束状居の細胞，並びに成熟ラットの被膜隣接細胞等発生学的に未熟と考えられる細胞には微細顆粒が 多く存在し，てれらの顆粒が集合した像が見出されることなどから，やはりこの可能性もあると考えられる。

\section{b) Mit. の形態の変化}

既述の如く，副緊皮質の Mit. はI 型と II 型とに大別するととが出来，I 型はII型より発生学的に未熟で あり，機能的にも活性が低い，何故なら，笨一に，I 型は未熟ラット副㭴皮質，成熟ラットでは被膜隣接細

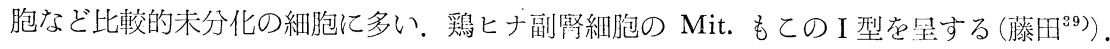

第二に, AGTH 或いは $\mathrm{Na} / \mathrm{K}$ 比低下などの刺激が加わると，I 型 Mit. の内膜突起の数か増加すると共 に蛇行し，時に断裂して複雑になり II型に近い棈造，即ち移行型になる。逆に，脳下垂体摘出，DOCA 投 与などで抑制すると，Mit.の内膜構造は比較的単純なI 型を旺するととがある。

以上の理由から， I 型 Mit. から II 型 Mit. への進展をFig.Aの如く想定した.

Rana esculata の副腎の電顕像でも，Geyer ${ }^{11)}$ は Mit. にやはり著者のI 型及びII 型に相当する型を区別 し， I 型から II 型への移行を推測している.

\section{(2) 副腎皮質機能と Organella の構造の变化との相互関係}

\section{a) 機能六進時の Mir. 及び小胞体の変化}

$\mathrm{ACTH}$ 或いは $\mathrm{Na} / \mathrm{K}$ 比低下などにより束状層或いは球状層の機能が充進すると，I 型 Mit. 及びII型 Mit. 共に限界膜の一部が開裂し，Mit. の内部と周辺の細胞質との接触が起る。かかる時, 細胞質には vesicular type の小胞体，Palade 顆粒，直径 $0.04 \mu の$ 特殊な小胞成分が增加している。乙れらの形態と Mit. 内 部の形態とが極めてよく相似しており，かつ両者の間に接虽の起るてとから，Mit. 内部と周辺の細胞質の 小胞体，顆粒之密接な関係にあるてとがわかる。

これらの小胞体, Palade 顆粒, 特殊な小胞成分は, 生化学的には microsome として一括される. Hayano et $\mathrm{al}^{18)}$ は副腎皮質の細胞内においては，全ての Corticoid の生合成は Mit.の表面で行なわれ，microsome fraction に存在する $3 \beta$-ol-dehydrogenase, soluble fraction に含まれる17-及び 21-dehydrogenase などの 所謂 extramitochondrial enzymes は，Mit. の表面に附着して活性化され，AGTH はとの活性化を促進 するとし，Mit. と microsomeの関係が密接であると主張しているが, 電顕的事実とよく合致する. ACTH は醉素蛋白の生合成をも促進するが (N. Saba $\left.{ }^{31)}\right)$ ，ACTH で刺激した場合，Palade 顆粒が増加するととは 新しい酵素蛋白の合成の結果と解される。

\section{b) 脂質顆粒について}

脂質顆粒の形成については，未熟ラットの観察所見の際述べた如く，滑面小胞体内にオスミウム好性物質 が沈着して，てれが次第に集樍し，融合して脂質颗精が形成されると考えている。高木 ${ }^{29}$ ， Suzuki ${ }^{22)}$ 等は， 肝細胞の脂質顆粒は滑面小胞体内に形成されると報告しているが， Suzuki の脂盺顆䊀形成の各段階を示す 電顕像と，副腎皮質細胞内の脂質顆粒の様々な状態の電顕像とは非常によく相似している.

Belt ${ }^{8}$ は microbody の内部に電子密度の高い物質の沈着を認めて抢り， microbody は Mit.のみでなく， 脂質顆粒の前駆体でもあろうと推察している。

既述の如く，Lever は Mit. の内部に電子密度の高い物質が沈着して，てれが次第に増大して脂質顆粒に なると報じているが，Mit. 内部に脂質顆粒の沈着が認められるのは，網状層の链質近接細胞のでく一部の Mit. で，他の首の細胞の Mit では極めて稀である，脳下垂体摘出ラットの菱縮した副腎ではてれが増加し てくる．Mit. 内部への沈着が進むと全体が 1 個の粗大な脂質顆粒になる。乙れら大小種々の粗大顆粒が集 合して大きな塊状を呈する場合もある(Fig.13)。乙の Mit. の変化は Rouiller \& Bernhard ${ }^{22}$ のいう硝子変性 に相当する，ての変性顆粒は球状首及び束状首に存在する小胞体から形成される脂質颗粒とは区別して考え るべきであろう。

ACTH で刺激すると，正常では球形の脂質顆粒は種々の不定な形に崩れるが，Mit.がてれに密接に附着 している. 恐らく Mit. はての脂質顆粒の代謝に関与しているのであろう.

脳下垂体を摘出すると束状層，網状首では脂質顆粒は粗大化するのに反し，DOCA を投与して球状層の 第 38 巻 第 9 号 
機能を抑制すると，脂質顆粒は消失する。従つてての脂質顆粒の消長は，機能との関連を求める際，適当な 指標とはいえない，むしろ Mit. 小胞体及び Palade 顆粒の変化が，忠実に皮質の機能を反映する.

Lever $^{6)}$ ，坂元 ${ }^{15}$ は脂質顆粒の内部に空胞形成を報し，機能と結び付けているが，オスミウム固定が不充分 だつたりすると，脂質顆粒内に同様の空胞形成が起り，人工的変化との区別が困難である．Fig. 6 の脂質顆 粒内の空胞は人工産物とみなされる，我々の種々の実験では，機能の変化に伴つて空胞が形成されるてとは なく, 従つて, この空胞に機能的意義はつけ難い.

\section{(3) Functional zonation の問題}

\section{a) 球状層亡脳下垂体亡の関係}

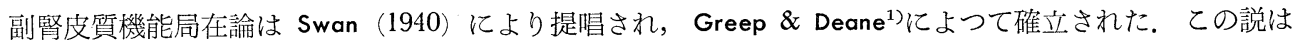
生化学の領域においても，牛の副腎皮質の各層の slice を基質液中で incubate した実験で，18-oxydaseの 活性は球状層だけに証明され，17-hydroxydase は束状層，網状層に，3 -dehydrogenase と21-hydroxylase の活性は両方の層に証明され，酵素分布の局在か確かめられた(Stachenko \& Giroud ${ }^{33)}$, Ayres $\left.^{34)}\right)$.

この機能局在論は, 球状首と脳下垂体との関係について種々の議論がなされている.

Deane \& Greep ${ }^{23}$ は，脳下垂体摘出により球状㬝は萎縮せず，逆に幅が広くなつてくるてとから，ての首 の自律性を強調している.

しかし，ACTH を投与すると球状酋の脂質顆粒が減少するととが報告されており (Wexler \& Rinfret $\left.{ }^{35}\right)$ 人においても ACTH を投与すると Aldosterone 排泗量が增加する(Bartter et $\left.\mathrm{al}^{366}\right)$ ).

本実験でも，ACTH を投与すると球状首の Mit. 及び小咆体に機能充進像か現われ，脳下垂体を摘出す ると術後 8 週目に球状圓の Mit. 小胞体に機能低下像を認めている.

故に，球状層の機能は $\mathrm{Na} / \mathrm{K}$ 比の変動によつて調節されるが，一方では脳下垂体前葉の影響を受けている とみなすのが妥当であうう。

\section{b) 束状層及び網状層の機能について}

ACTH を投与すると, 束状層外層の Mit., 小胞体等の organella が最も著明な機能充進像を呈し, 脳下 垂体を摘出すると, やはりこの束状屏外首の organella が一番強い機能低下像を示す。

しかるに, Chorionic gonadotrophin を投与すると, 束状屏内犚及び網状層外首の organella そ変化が起

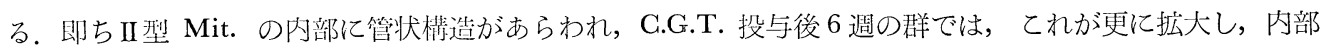
に電子密度の低い物質を满たした空胞様の胞体に変化する。既述の如く，かかる Mit. の変化は AGTH 投 与の場合とは異なる。

西川 ${ }^{37}$ は尿中17-KSの分劃の年令的推移を研究し, 老年期に入り睪丸機能が減退すると, 辤丸由来の androsterone + etiocholanolone 分剒が減少するが，その時，下垂体 gonadotrophin が增加して，副軙皮質の

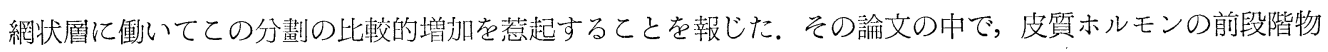
質に対して ACTH と gonadotrophin が翼なつた醉素系を賦活し, 一方は cortisone, hydrocortisone 他 方は androsterone 及び eticholanolone へ導くと推論している. AGTH 投与と G.G.T. 投与の場合とで, Mit. の形態の変化がかくの如く異なつているととは，ての推論の裹付けといえる.

又, 束状層内層及び網状首外圆の Mit. の形態が， gonadotrophin 投与によつて特異的に変化することか ら，ての首は副腎性性ホルモンの代謝に関与していることがわかる.

\section{5. 結}

論

未熟及び成熟ラット副緊皮質を電子顕微鏡にて観察し，Mit. の新生と進展の問題を明らかにすると共に， $\mathrm{ACTH}$ 投与, 脳下垂体摘出, $\mathrm{KCl}$ 投与による $\mathrm{Na} / \mathrm{K}$ 比の低下, DOGA 投与, C.G.T 投与等の実験を行 ない，副腎皮質の微細構造と機能との関連に対する考察を行なつて，次の結論を得た。

（1） Mit. は内膜の構造から cristae 或いは filament 状の内膜乫起を有する I 型と, 蜂䆚状の内膜構造 を呈するエ型とに分類される，前者は球状㜿，後者は束状層及び網状層に主として分布する． 
Mit. は microbody から形成されると推定される。ラットが成熟するに従い，或いは㙨能が艺進すると， I 型 Mit. の内膜突起が蛇行して複雑になり，断裂して II 型 Mit. に移行する.

機能光進状態が更に続くと，Mit. 限界膜のでく一部は開裂し，Mit. 内部と周辺の小胞体等との接触が起 る.

（2）ACTH 投与及び脳下垂体摘出により，束状層のみならず球状層の organella の形態も変化し，乙 机々间様の変化が， $\mathrm{Na} / \mathrm{K}$ 比の低下及び DOCA 投与の際も起る. よつて球状層の機能は $\mathrm{Na} / \mathrm{K}$ 比の変動 により調節されるが，一方，脳下垂体前葉の響影も受けているととがわかる。

（3） C.G.T. 投与により，束状層内層及び網状屓外首のII型 Mit. の内部に管状構造が生じ，更に投与を 続けると 6 週後にはてれが拡大し, 空胞様の胞体に変化する.

稿を終るに当り，終始御兓篤なる御指導と御校閲を睗つた恩師西川光夫教授に梁甚なる感謝を捧げ，併せ て常に御教示を戴いた共同研究者室根博士に謝意志表する。同時に電顕的観察ならびに撮影飞御協力下さつ た新潟大学電子顕微鏡室技術員齊藤信氏に感謝する。

本論文の要旨は，第32，33打よび34回日本内分必学会総会に㧊いて発表した。

\section{文献}

1) GREEP, R.O. and H.W. DEANE : Ann. N.Y. Acad. Sci., $50: 596$, (1949).

2) BOTELLALLUSIA, J. : Archiv. Gynäkologie ; $17: 183$, (1952).

3) CHESTER JONES, I : The Adrenal Cortex, Cambridge University Press. (1957). 4) BRAUNSTEINER, H., K. FELLINGER and F. PAKESCH : Wien. Z. Inn. Med., $36: 281$, (1955).

5) LEVER, J.D. : Am. J. Anat., $97: 3$, (1955). $\quad 6)$ LEVER, J.D. : Endocrinol., $58: 163$, (1956). $\quad$ 7) LEVER, J.D. : J. Bioph. Biochem. Cytol., 2 : No. 4, Suppl. 313, (1956). 8) BELT, W.D. : J. Bioph, Biochem. Cytol., 4 : 337, (1958). 9) De ROBERTIS, E.D.P. and D.D. SABATINI : J. Bioph. Biochem. Cytol., $4: 667$, (1958). 10) ROSS, M.H., G.D. PAPPAS, J.T. LANMAN and J. LIND : J. Bioph. Biochem. Gytol., $4: 657$, (1958).

11) GEYER, G : Acta histochem., $8: 223$, (1959).

12) ASHWORTH, G.T., G.J. RAGE and H.H. MOLlENHAUER : Am. J. Path., $35: 425$, (1959). ZELANDER, T. : J. Ultrastructure Res., Suppl. $2: 1$, (1959).

14) 本陣良平, 泉外美, 中村俊 男 : 解剖誌, 32 ：附録 16 回中部地方会抄録 1, (1957).

15) 坂元栄 : 日内分泌誌, $35: 711(1959)$. 16) 吉村不二夫：日内分泌誌，37：495 (1961)。 17) 斉藤真：日産婦誌，12:11 (1960)。 18) HAYANO, M., N. SABA, R.I. DORFMAN and O. HECHTER : Recent Prog. Hormone Research. $12: 79$ (1956).

19) NISHIKAWA M., I. MURONE and T. SATO : Electron Microscopic Investigations of the Adrenal Cortex. Endocrinol, (in press). 20) BEAMS, H.W., T.N. TAHMISIANand R.L. DEVINE : J. Biophysic. and Biochem. Gytol., 1:197, (1955). 21) POWER, E.L., C.F. EHRET, L.E. ROTH and O.T. MINIGK : J. Biophysic. and Biochem. Cytol., Z. Suppl. : 341, (1956). 22) ROUILLER, C. and W. BERNHARD : J. Biophysic. and Biochem. Cytol., Z. Suppl. 355, (1956). 23) DEANE, H.W. and R.O. GREEP : Am.J. Anat., $79: 117$, (1946). 24) DEANE, H.W. and R.O. GREEP : Endocrinol, $43: 133$, (1948). 25) SINGER, B. and M.P. STARKE-DUNNE : J. Endocrinol., $12: 130$, (1955). 26$)$ SARASON, E.L. : Arch. Path., 35 : 373, (1943). 27) SELYE, H. and H. STONE : On the Experimental Morphology of the Adrenal Gland. American Lecture Series. Springfield, Illinois : C.C. Thomas. (1950). 28) 高木文一 : 「日本の医学の1959年」(第15回日本医学会総会学術集会記録, 東京) $1: 70$ 29) RHODIN, J : Correlation of Ultrastructual Organization and Function in Normal and Experimentally changed proximal Convoluted Cells of the Mouse Kidney. Karolinsk Instituent, Stockholm. (1954). 30) 藤 田尚男, 安田勝, 永田士郎 : 日内分泌誌, $37: 260$ (1961).

31) SABA, N : Biochem. Societ. 
佐藤論文附図（その 1)
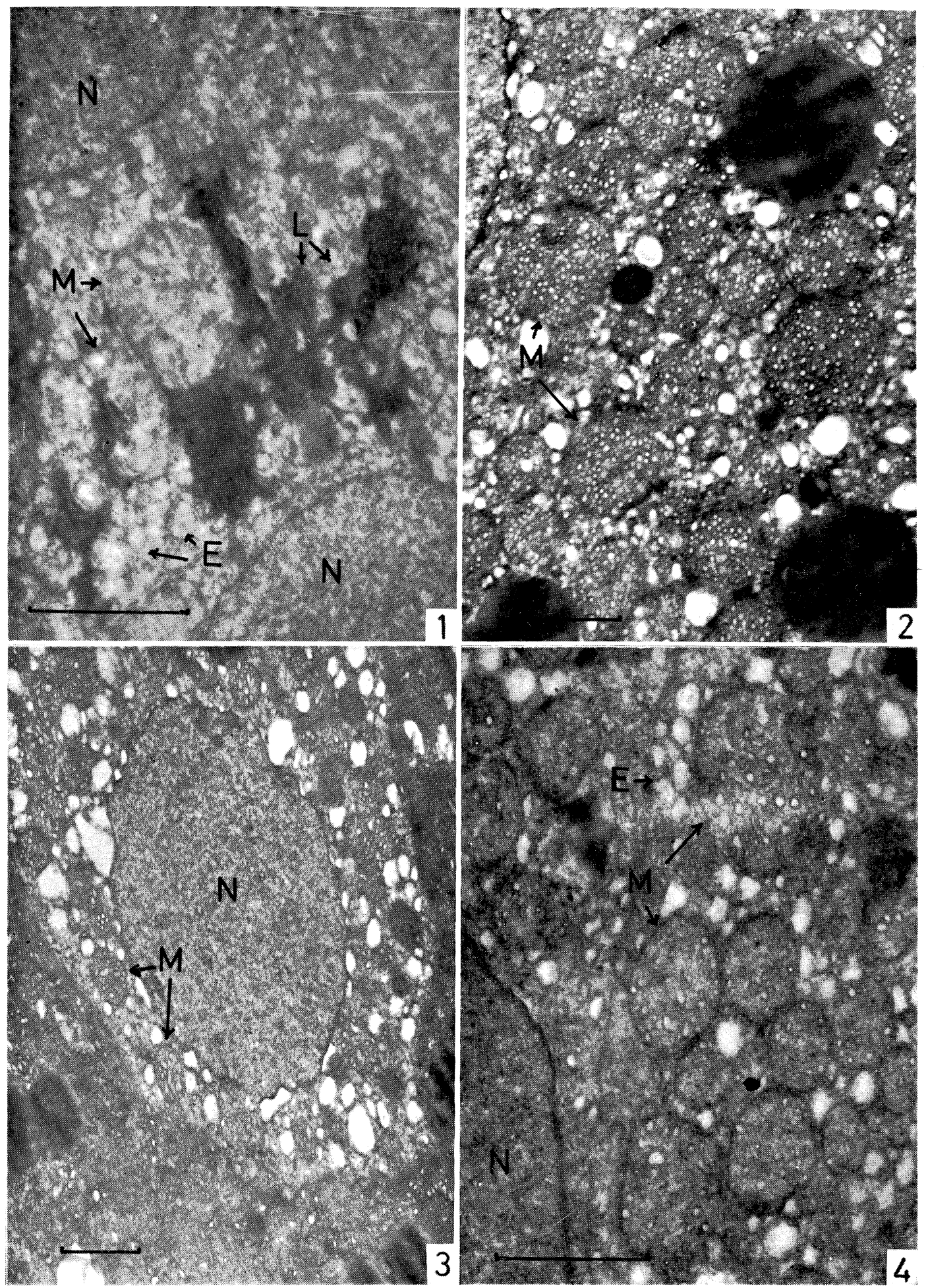


\section{佐 藤 論文附図（その2）}
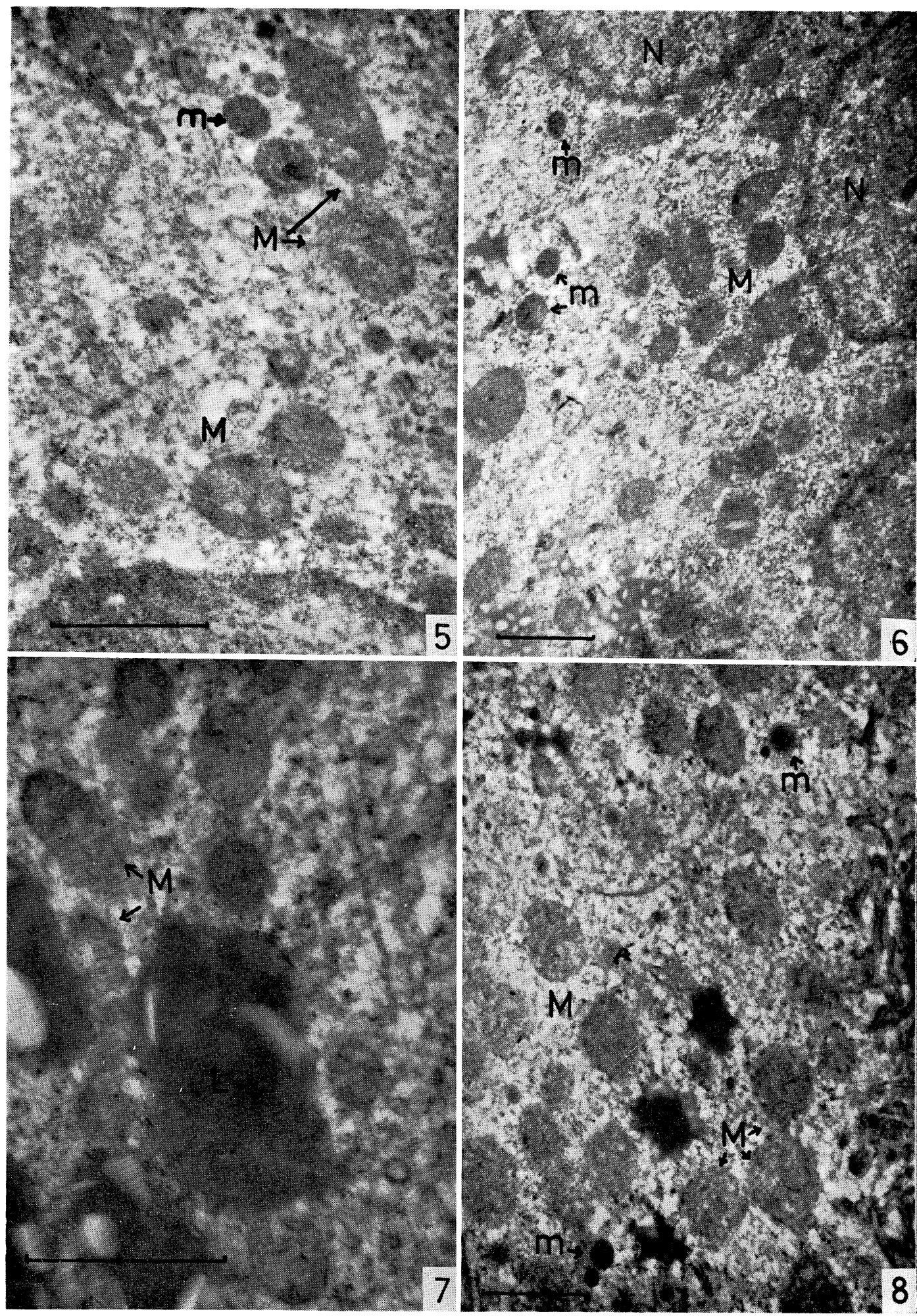

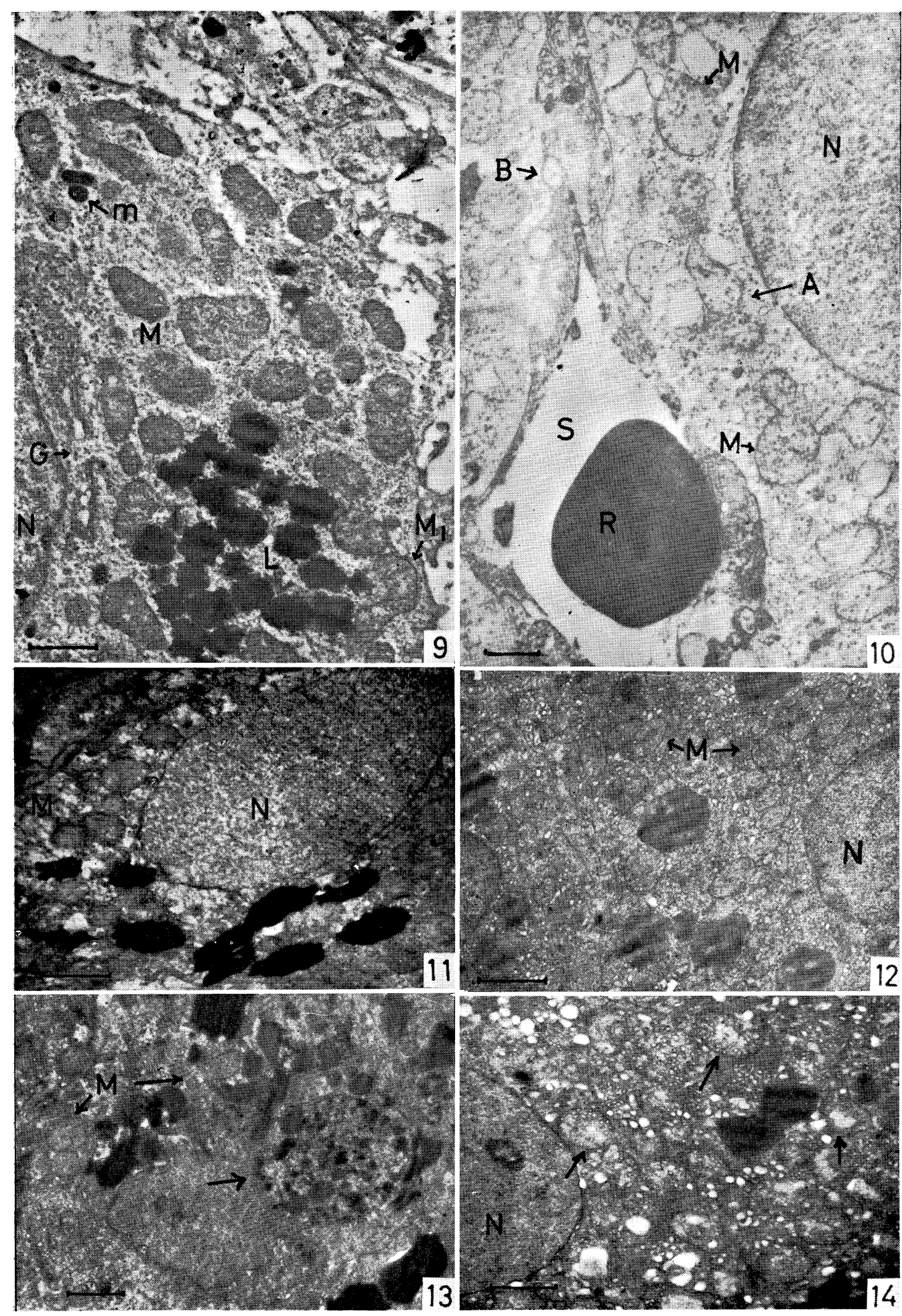
佐藤 論文附図（その 4)

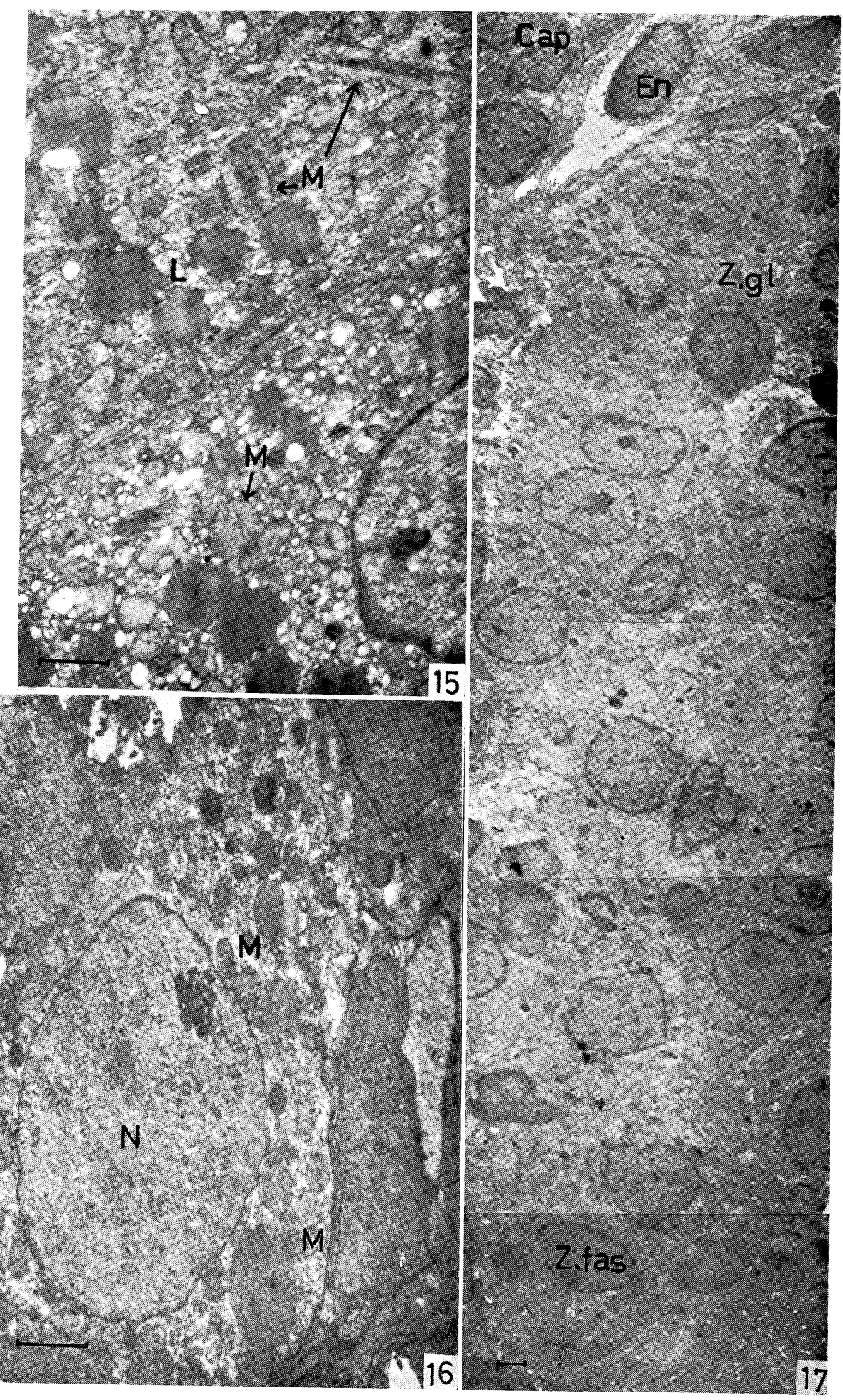


Symposia, I8: 96, (1960).

32) SUZUKI, Y : J. Electronmicroscopy, $9: 24$ (1960).

33) STACHENKO, J. and C.J.P. GIROUD : Endocrinol., $64: 730$, (1959).

34) AYRES, P.J. :

Biochem. Societ. Symposia, $18: 50,(1960)$.

35) WEXLER, B.C. and A.P. Rinfret : Endocrinol., 57 : 608, (1955).

36) RARTTER, F.C., I.

Prog. Hormon Research, $15: 311$, (1959).

37) 西川光夫 : 最新医学, $10: 1091,(1955)$; 老年病

学, II : 343, (1957), 金原出版.

\section{写真 説 明 \\ 略 号 説 明}

$\mathrm{M}$ : mitochondria $\mathrm{E}$ : endoplasmic reticulum $\mathrm{L}$ : lipid granule $\mathrm{m}:$ microbody $\mathrm{N}:$ nucleus G : Golgi apparatus S : sinusoid R : red blood cell.

Fig. 1 正常成熟ラット球状層のI 型 Mit. と脂質顆粒. 写真左下の所見は小胞体内に脂質顆粒が沈着して くる状態と考えられる。 $25.000 \times$

Fig. 2 正常成熟ラット束状尿の II A 型 Mit. $16.000 \times$

Fig. 3 正常成熟ラット網状層の暗細胞と明細胞, II B 型の Mit. が明胞胞に認められる. $12.000 \times$

Fig. 4 正常成熟ラット束状層外首. I 型 Mit. とII型 Mit. の移行型が認められる. $24.000 \times$

Fig. 5 生後 5 日の未熟ラット球状風. I 型 Mit. が散見される。 $24.000 \times$

Fig. 6 生後 5 日の未熟ラット束状層. II 型 Mit. 及び microbody が認められる. $15.000 \times$

Fig. 7 生後10日の未熟ラット球状首，脂質顆粒に I 型 Mit. が接している. $30.000 \times$

Fig. 8 生後10日の未熟ラット束状層. II 型 Mit. 及び microbody が認められる. 生後 5 日のラットに比 しII型 Mit. がかなり増加してきている。 $16.000 \times$

Fig. 9 ACTH-Z 投与後 2 週間目のラット球状層. I 型 Mit. が移行型 Mit.に変る. 桿状に延びている Mit. $\left(\mathbf{M}_{1}\right)$ も認められる。数個の脂質顆粒が集合して集団を形成し，それ蛋 Mit. が取り国んでいる 像が認められる。核の附近に Golgi apparatus が発達している。10.000×

Fig. 10 ACTH-Z 投与後 3 週間のラット束状層. II 型 Mit. の限界膜が開裂し, Mit. 内部と細胞質との交 流がみられる。(矢印 A) 叉，小胞体が細胞膜に開口している像が認められる。（矢印 B $8.000 \times$

Fig. 11 脳下蓋体摘出後 8 週間のラット球状層. I 型 Mit. の内部構造は不明膫となる. $10.000 \times$

Fig. 12 脳下垂体摘出後 1 週間のラット束状層. Mit. の内部構造不明瞭となり，小胞体も減少. このため細 胞全体が暗調走旺す. $10.000 \times$

Fig. 13 脳下垂体摘出後 4 週間のラット網状首. 脂質顆粒がいくつか集合し，一つの大きな塊となつている. (矢印) $8.000 \times$

Fig. 14 Chorionic gonadotrophin 投与後 6 週. Mit. 内部に管状構造があらわれ，その一部は空胞様の胞 体に変化するが，乙の胞体内部は電子密度の低い物質で満たれている．（矢印） $10.000 \times$.

Fig.15 KCl 投与11時間後球状首. Mit. の増加及び膨大が起る。一部の Mit. 内には数本の束になつてい る細管が認められる。10.000×

Fig. 16 DOGA 投与 5 週間後の球状首。Mit. の内部構造は不明瞭となり，同時に matrix の電子密度は高 まり，Mit. は時調を呈する。10.000×

Fig. 17 DOCA 投与 8 週間. 被膜 (Cap.) から球状層 (Z. gl) 及び束状首 (Z. fas) の一部まで含む切片. 脂質 顆粒の減少している状態がよくわかる. En : Subcapsular sinus の内皮細胞. $3.800 \times$ 